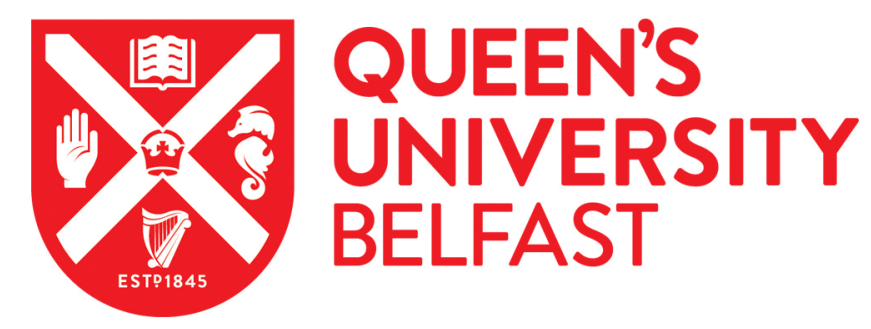

\title{
Explaining Institutional Strength: The case of national human rights institutions in Europe and its Neighbourhood
}

Lacatus, C. (2019). Explaining Institutional Strength: The case of national human rights institutions in Europe and its Neighbourhood. Journal of European Public Policy, 26(11), 1657-1677.

https://doi.org/10.1080/13501763.2018.1545795

Published in:

Journal of European Public Policy

Document Version:

Peer reviewed version

Queen's University Belfast - Research Portal:

Link to publication record in Queen's University Belfast Research Portal

Publisher rights

Copyright 2019 T\& F. This work is made available online in accordance with the publisher's policies. Please refer to any applicable terms of use of the publisher.

\section{General rights}

Copyright for the publications made accessible via the Queen's University Belfast Research Portal is retained by the author(s) and / or other copyright owners and it is a condition of accessing these publications that users recognise and abide by the legal requirements associated with these rights.

Take down policy

The Research Portal is Queen's institutional repository that provides access to Queen's research output. Every effort has been made to ensure that content in the Research Portal does not infringe any person's rights, or applicable UK laws. If you discover content in the Research Portal that you believe breaches copyright or violates any law, please contact openaccess@qub.ac.uk. 


\title{
Explaining Institutional Strength: The case of national human rights institutions in
}

\author{
Europe and Its Neighbourhood
}

\author{
Corina Lacatus
}

\begin{abstract}
National human rights institutions have spread rapidly across Europe and its Neighbourhood consolidating their powers to protect human rights. Yet, we know little about the causes for change in the strength of national human rights institutions over time. We propose an analysis of institutional strength along two dimensions of safeguards - durability and enforcement based on original data for 50 states. We illustrate the quantitative analysis with two case studies - Hungary and Poland. We find that European Union membership conditionality is the strongest predictor of increased strength in national human rights institutions. Additionally, we find evidence of democratic 'lock-in', as newly democratised states seek to increase the durability of their institutions. The influence of the United Nations and the European Union, through state networks, increases the strength of national human rights institutions, particularly their durability. The Council of Europe has a positive impact on the institutional safeguards for enforcement.
\end{abstract}

Keywords: institutional strength, Europe, European Neighbourhood Policy, Hungary, national human rights institutions, Poland 
In the past two decades, national human rights institutions (NHRIs) have become increasingly important institutional actors in Europe. As the main independent domestic bodies charged with the implementation of international human rights treaties ratified by governments (de Beco 2007), human rights ombudsmen and human rights commissions play the dual role of promoting and protecting rights at the national level. NHRIs are key to countries' efforts to address adequately a range of rights-related issues like the protection and promotion of fundamental rights, social and political rights. Recent political developments in a number of European countries, most notably in Hungary and Poland, indicate that human rights can be reversed by governments with illiberal agendas. Operating in increasingly hostile national contexts, human rights institutions face more direct threats to their independence and effective functioning. If the space for human rights is shrinking, how well-equipped are NHRIs to maintain their independence and carry out their mandates?

The rise of NHRIs has spawned debate in the fields of international relations and international law. Described as "domestic non-judicial institution[s] for the implementation of human rights law" (Reif 2004), NHRIs serve to embed international norms in local structures (Cardenas 2003). Most academic research to date has focused on the diffusion of human rights ombudsmen and commissions (Cardenas 2014; Goodman and Pegram 2012; Kim 2013; Koo and Ramirez 2009; Lacatus 2018; Pegram 2010; Reif 2004), providing explanations for states' decisions to establish NHRIs. In addition, several institutional reports and academic articles explore the effectiveness with which NHRIs carry out their mandates and improve human rights records (Cardenas and Flibbert 2005; Carver 2014; Linos and Pegram 2017; Mertus 2009; Murray 2007; Welch 2017), offering evidence in favour of the role that NHRIs play for improving human rights outcomes. Recent scholarship opened a new research agenda on the institutional design of NHRIs, explaining why states decide to grant NHRI certain mandated powers (Linos and Pegram 2016b), offering evidence that the Paris Principles, a global 
normative standard endorsed by the United Nations (UN), has had a significant impact on countries' decisions to establish NHRIs and endow them with certain institutional designs.

While scholars have provided valuable insights into institutional diffusion and the different categories of design safeguards that countries decide to adopt, the choices that states make with regard to the strength of their institutional design is not fully understood. For instance, it is important to move beyond considerations of whether or not institutions are independent by design by asking also how independent they are. This helps us shed light on why in some countries, NHRIs are more or less autonomous from government than in others. Or why certain NHRIs have comparatively stronger or weaker mandated safeguards that guarantee longevity and effectiveness. Ultimately, these considerations of institutional strength will help us appreciate why institutional design choices matter as guarantees for more durable and effective human rights institutions.

To address these questions, we propose the first study of NHRI strength. We draw from the literature on institutional strength (Levitsky and Murillo 2013; Sedelmeier 2009), to investigate the determinants of NHRI strength at the regional level, in Europe and its Neighbourhood. Institutional strength consists of a set of formal and written rules about two main dimensions of safeguards that seek to guarantee the durability of these institutions and the extent to which these rules are followed in institutional practice: durability safeguards and enforcement safeguards. Variation in institutional safeguards across time is often reflected in changes in mandates, amendments of country constitutions or laws that give NHRIs legal status and in priorities of institutional activity included in annual reports. This study works under the assumption that we are well-served by a systematic study of institutional strength before we seek to explore NHRI effectiveness in changing human rights outcomes. Although the analysis of institutional impact is beyond the scope of this paper, our analysis of institutional strength 
is an important step toward understanding the main determinants of compliance with international human rights.

One of the main theoretical contributions of our work is bringing together insights from the literatures on institutional design, institutional strength, cross-border diffusion and Europeanisation. We build on existing scholarship showing that international organisations (IOs) exert a significant influence on the design of human rights institutions. This is particularly salient in the case of international organisations that coordinate networks with restrictive membership rules and clearly defined norms of appropriate behaviour (Goodman and Jinks 2013; Simmons et al. 2008).

Recent research has offered compelling evidence that the impact of the UN, especially the institutional network coordinated by the Office of the High Commissioner for Human Rights (OHCHR), on NHRI design is positive and significant globally (Linos and Pegram 2016b; Linos and Pegram 2016a). This impact is related to the spread of a novel human rights norm, the Paris Principles, formulated in 1991 and adopted by the General Assembly in 1993, which lay out the main criteria of design for NHRIs around the world and form the standard on which the OHCHR carries out an accreditation process for NHRIs that seek to become members of the network of NHRIs, Global Alliance of National Human Rights Institutions (GANHRI). While scholars have provided valuable insights into the impact of the UN on NHRI design at one particular point in time, the impact of the UN on NHRI strength over time is yet to be tested. Equally important, the impact of other IOs with strict membership ties on governments' choices regarding NHRIs, such as the European Union (EU), needs further exploration.

In this study, we investigate the determinants of NHRI strength in Europe. We propose an original dependent variable - NHRI strength- and an original data set that provides insight into variation in strength across countries and across time, along eleven different indicators and 
two main dimensions of NHRI design safeguards for durability and enforcement. Unlike most previous studies that have measured NHRI diffusion and design features as binary, we propose a four-point scale of assessment of the strength of each design safeguard. The paper proposes an original data set that explores changes in strength during 1994-2017 in fifty NHRIs, including institutions in EU member states, states with EU membership candidate status and member states of the European Neighbourhood Policy (ENP).

The focus on Europe and its Neighbourhood is justified theoretically and empirically. Existing literature provides compelling evidence that socialisation effects can be at work in the case of EU members and that, for recent members and candidate countries, conditionality tied to EU membership may also an important factor explaining states NHRI diffusion (Carver 2011; de Beco 2007; Pegram 2010; Wouters et al. 2013). In the case of the ENP, socialisation and conditionality are less effective and conducive to policy and institutional change, in particular when the promise of EU membership is absent (Schimmelfennig 2012; Sedelmeier 2007). Change in institutional strength across Europe and its Neighbourhood shows a constant increase, with new institutions appearing and existing ones increasing their design over the years. Yet, we have still to explore whether this success holds over time.

The analysis responds to the recent call by Goodman and Jinks (2013), for an examination of mechanisms explaining social influence and state behaviour on human rights. We examine three main mechanisms of social influence and norm diffusion - persuasion, acculturation, and indirect coercion through EU conditionality - and proposes three hypotheses testing for the effect that IOs may have on NHRI strength. The analysis provides evidence in support of acculturation and persuasion-based explanations for the strength of NHRIs in Europe. We find that membership in GANHRI, the NHRI network coordinated by the UN through a peer-review accreditation system, is associated with stronger NHRIs over time, especially with the design safeguards for durability. This finding points in the direction of 
isomorphism as linked to institutional durability, in an effort for countries to meet the requirements stated in the Paris Principles.

The analysis finds that EU member states have stronger NHRIs overall, although this effect does not remain statistically significant on both dimensions of durability and enforcement. This can be an indication of successful persuasion processes and democratic norm diffusion coordinated by the EU. The influence of human rights norm diffusion at the regional level is also supported by the positive impact that the regional regime of regional human rights treaties has on NHRI strength. We find that European states that have ratified a larger number of the regional human rights mechanisms have NHRIs with stronger safeguards for enforcement.

We add new empirical evidence to the scholarship that explores democratic institutional performance in post-communist states. We find that EU conditionality has an overall positive effect on NHRI strength, on both dimensions of institutional strength. Our findings lend unequivocal support to conditionality-based explanations of stronger human rights institutions and point to the importance of considering the effect of EU conditionality on NHRIs alongside a consideration of the national context and its impact on institutional strength. Our results find a marginally significant effect of democratisation on NHRI strength, as governments in newly democratised states have increased the strength of their NHRIs over time, particularly institutional stability.

We illustrate our analysis with a qualitative assessment of the strength of NHRIs in Poland and Hungary, where the ombudsmen bodies have been some of the strongest in Europe, by design. We show that they have maintained their strength over the years, despite reforms to the legal system that have violated human rights in both countries. Finally, we consider also points of vulnerability in the new design of the Hungarian ombudsman, which can lead to a weaker institutional performance and effectiveness. 


\section{NHRIs as national actors with regional and global support}

Since the early 1990s, NHRIs have spread rapidly across borders. They have become key actors in the domestic implementation of international human rights law, enjoying support from regional and global IOs. In 1994, the UN adopted a set of criteria - the Paris Principles - that specified their core functions and design features of NHRI (OHCHR 2016). These Principles lay emphasis on the necessity to observe a number of principles such as pluralism and independence, while maintaining a broad human rights mandate, providing advice to governments and monitoring of human rights violations. The General Assembly emphasized that a state establishing an NHRI has "the right to choose the framework that is best suited to its particular needs at the national level" (UN General Assembly 1993).

In Europe, the Council of Europe $(\mathrm{CoE})$ was the first to encourage the creation of NHRIs and their cooperation with EU institutions in the 1990s (Council of Europe 1997). Over the years, the European Union Agency for Fundamental Rights, the CoE, and Organization for Security and Co-operation in Europe have specifically targeted the development of NHRIs across the region by encouraging further integration of NHRIs in domestic and regional efforts to implement human rights, by co-ordinating trainings, information sessions, and facilitating the annual meetings of the regional network of NHRIs.

Additionally, the EU has coordinated the efforts directed at strengthening the capacity of NHRIs through including NHRIs in instruments that bind participating states to standards of human rights performance. The European Instrument for Democracy and Human Rights supports NHRIs to strengthen their role as key national actors mandated to promote and protect human rights in line with the Paris Principles. Importantly, the EU has increased its reliance on NHRIs as key actors in the enlargement process. Assessments of NHRI performance and 
recommendations for strengthening capacity and effectiveness are included in the annual country reports of states that have had candidate status to EU membership. The European Commission also includes NHRIs are its bi-annual monitoring reports on corruption control in Romania and Bulgaria, part of the Cooperation and Verification Mechanism.

How have the UN and the EU influenced variation in NHRI strength across Europe and the ENP?

Mechanisms explaining NHRI strength: persuasion, acculturation, and coercion

Drawing from the literatures on cross-border diffusion of liberalism (Simmons 2002; Simmons et al. 2006; Simmons and Elkins 2004), on social influence for human rights (Börzel 2012; Goodman and Jinks 2013) and on Europeanisation in candidate and new member states (Sedelmeier 2011), this section focuses on three main mechanisms - persuasion, acculturation and coercion (Goodman and Jinks 2013).

Persuasion is the mechanism that ties social influence to learning and information sharing among actors, be they individuals, institutions, or states (Finnemore and Sikkink 1998; Goodman and Jinks 2013; Keck and Sikkink 1998; Risse 2000). IOs and transnational networks provide the right environment for learning through argument and deliberation (Johnston 2001). Networks act as environments where members are socialized into following rules and norms considered appropriate in that community. When successful, persuasion results in complex learning by which actors 'internalize' new norms and rules of appropriate behaviour and reconfigure their interests and identities accordingly (Checkel 2005). In time, values and norms can change and can generate coordinated shifts in interests and behaviour across borders and institutions (Finnemore 1993; Risse-Kappen et al. 1999). 
Acculturation shows that learning can be incomplete and that it could stop short of persuasion and full identification with the norms and practices of the reference group (Goodman and Jinks 2013; Hatch 1989; Johnston 2001). Institutional change can take place as a result of new learned values and norms, but the process of internalisation of these norms and values is incomplete and not driven by the content of the learning but rather by the interest to conform to the rules and practices of a community (Meyer and Rowan 1977; Powell and DiMaggio 1991; Yzer 2012; Zucker 1987). Persuasion requires that an actor accepts the validity or legitimacy of a set of beliefs, practices or norms. Acculturation builds solely on the actor's perception that an important reference group holds the belief, engages in the practice, or subscribes to the norm.

In the case of NHRIs, persuasion is successful when domestic actors show continued support for a robust and effective institution over time, as learning will result in not only more durable NHRIs but also in institutions with stronger safeguards for the enforcement of their human rights mandate. When learning leads to a transformation of beliefs and an internationalisation of norms, the strength of NHRIs remains high or maintains a continued course of improvement in the cases of institutions that were weaker at the time of their establishment. In the case of acculturation, we expect that countries join global and regional networks of NHRIs in order to align with other countries' behaviour and not necessarily because the content of the norms is considered directly relevant. We expect that the effects of acculturation processes will be more visible through the creation of institutions with stronger safeguards for durability, but with relatively weaker safeguards for enforcement.

Scholars have found that the OHCHR, through GANHRI, has played an important role in the diffusion of NHRIs (Cardenas 2003; Kim 2013; Linos and Pegram 2016a). The restrictive model of membership in GANHRI, coupled with a system of monitoring based on peer-review is particularly well suited for persuasion, although likely to be ineffective or 
counterproductive in mobilizing the social and cognitive pressures linked with acculturation (Goodman and Jinks 2013). Through the accreditation and re-accreditation process, GANHRI provides NHRIs with an independent system of monitoring institutional design and performance. On the basis of a peer-review process, GANHRI offers NHRIs regular feedback and recommendations on how to strengthen institutional capacity. It also offers member NHRIs a formal framework for exchange of ideas regarding the improvement of institutional performance.

We hypothesise that countries participating in the GANHRI peer-review accreditation process will have stronger NHRIs than those that have NHRIs without accreditation (H1).

At the regional level, the EU is arguably the most influential actor in changing norms and institutional practices on human rights. The EU can be seen a "teacher of norms" in its relationship with member states and accession candidates, as a large scale socialisation agency that actively seeks to promote rules, norms, practices and structures of meaning (Börzel 2012; Goodman and Jinks 2013). One manifestation of this normative influence, which leads to persuasion and learning, can manifest through the influence of EU membership. Scholarship on EU governance points to two approaches for understanding EU influence. First, the internal governance of the EU usually focuses on policy-making within the EU (Jachtenfuchs 2001; Kohler-Koch and Eising 1999). Second, the external dimension of EU governance is exclusively about the transfer of given EU rules and their adoption by non-member states (Schimmelfennig and Sedelmeier 2004).

In Europe, EU conditionality constitutes the coercive strategy associated with greater success at inducing better behaviour than typical international human rights agreements (Hafner-Burton 2005; Hafner-Burton 2009). Scholars of NHRI diffusion have found that EU membership conditionality has been an effective coercive tool for the establishment of NHRIs in Central and Eastern Europe (CEEC) (Carver 2011; Pegram 2010). Despite democratic 
conditionality being different for different candidate states, many observers agree that, overall, EU conditionality has been successful in promoting political change in the region and contributed to an increase in the quality of democracy and rights protection (Hafner-Burton 2005; Hafner-Burton and Ron 2009; Kelley 2004; Roberts 2010; Vachudová 2005).

Political conditionality has not been uniformly effective in advancing democratisation since it was established in preparation for the 2004 wave of EU accession. Some countries Hungary, Poland, and the Czech Republic - were already on their way to democratic consolidation by the start of the negotiations and EU conditionality. Political conditionality has had the most significant impact in those CEECs situated between these extremes and had credible EU membership perspective, where it contributed to the consolidation of liberal forces and motivated liberal parties in government to advance Western integration and thus raise the cost of potential future reversal (Schimmelfennig et al. 2006).

Political transitions are tied to domestic elites seeking democratic consolidation and committing to 'lock-in' reforms through institutionalisation to advance democratisation and diminish the opportunity of future backsliding (Moravcsik 1995; Moravcsik 2000a; Simmons 2009). Evidence of continued success in the post-accession period is mixed, with a number of scholars remaining positive (Levitz and Pop-Elechies 2010; Schimmelfennig and Sedelmeier 2004; Sedelmeier 2009). In the field of human rights, commitments remain shallow and transitions to rights-respecting democracies are reversible (Conant 2014).

The CoE is a central actor in Europe's human rights architecture. With a long history of human rights promotion and protection and a membership that spans more widely than the EU membership, the CoE has played a key role in norm diffusion in the region (Manners 2002; Shyrokykh 2019). The CoE oversees a dense network of human rights treaties and protocols that members can ratify. In 1999, the CoE established the Commissioner for Human Rights, as an independent and impartial non-judicial institution mandated to engage in dialogue with 
member states. Through collaborative programmes, country visits, awareness-raising campaigns and tailored advice to domestic actors, the Commissioner has offered support for the implementation of regional human rights treaties and has promoted the development of stronger national human rights structures.

We propose three hypotheses testing the social influence of the EU. First, we expect that the influence of the EU membership on NHRI strength will be positive (H2). Second, the influence of a stronger commitment to the CoE through regional human rights treaties on NHRI strength will be positive (H3). Third, candidate countries that have been subjected to EU conditionality have stronger NHRIs (H4).

\section{Toward a definition and a measurement of NHRI strength}

We conceptualise NHRI strength along two main dimensions: enforcement and durability. Enforcement represents the extent to which 'on paper', parchment rules are complied with in practice (Levitsky and Murillo 2009). Enforcement powers are embedded in the design safeguards of the institution allowing it to carry out its mandate. An important dimension of enforcement safeguards in the case of NHRIs is the autonomy they have from government interference in their work (Linos and Pegram 2016a; Linos and Pegram 2016b; Smith 2006). Independence from government can take different forms and is manifest in the sources of financial support, built into the appointment system for institutional leadership and institutional decision-making structures.

Key to understanding government support for institutional strength, in particular for strong institutional enforcement safeguards, is the distinction between formal compliance, or the formal adoption of rules, and behavioural compliance, or behavioural rule adoption (Schimmelfennig and Sedelmeier 2005). The inclusion in institutional mandates of strong 
safeguards for enforcement does not necessarily result in more effective institutions. Governments can endow NHRIs with strong mandates, to indicate compliance with external requirements imposed by IOs, but they do not necessarily have to support their NHRIs to carry out their mandates. If they intend to curb the effectiveness of their institutions, they can allocate insufficient funds, or no resources beyond minimum requirements, making them unable to enforce the mandated powers they hold (Sedelmeier 2009).

Durability is defined as the ability of institutions to survive the passage of time and changes in conditions in the social and political environments in which they operate (Levitsky and Murillo 2009). Most NHRIs have safeguards for their durability built into their designs, such as their legal status embedded into country constitutions or through statutory law, as opposed to a decree or some other document. Particularly evident in transitional democratic states, these safeguards are often intended to ensure a certain 'lock-in' of human rights institutions in the domestic context and their protection from future attempts to weaken them.

The theory of institutional strength informed the coding of institutional safeguards for NHRIs in Europe along two main dimensions of institutional strength safeguards - durability and enforcement, - capturing eleven indicators and six different dimensions of institutional design (See Appendix). Durability is operationalised along three dimensions. First, the legal status of the NHRI by inclusion in the national constitution, national law, or other official document, is a parchment rule that seeks to ensure the durability of the institution in legal terms. The second dimension measures the degree to which the mandate includes human rights as a unique or main area of the work. The third safeguard consists of the rules that define the powers of human rights promotion and protection of each NHRI.

To measure enforcement safeguards, we operationalise three main dimensions. The first dimension captures the safeguards that ensure the NHRI's independence from government intervention, measured in terms of financial autonomy, the degree of government input in the 
process of appointing institutional leadership, and institutional reporting structure. The second dimension measures the predominant activities of promotion and protection that NHRIs perform. The third dimension captures the extent to which an NHRI includes civil society representatives in decision-making, as one measure of plurality.

Building on existing scholarship, we propose also a number of control variables (See Appendix for operationalization). We expect that democracies in general (Linos and Pegram 2016b) and the democratic frontrunners among new democracies (Moravcsik 2000a; Schimmelfennig and Sedelmeier 2004) will have stronger NHRIs. Moreover, lower- and middle-income countries are more likely to engage in institutional borrowing (Wayland 2004), even when governments do not intend to enforce these institutions (Van de Walle 2001). The models include also a binary control variable a common system of law (Linos and Pegram 2016b).

\section{A quantitative analysis of NHRI strength}

We collected original data on eleven ordered categorical indicators of NHRI strength in fifty countries for the period 1994-2017. Along each of the eleven indicators, institutions are coded as weak, medium, strong, or non-existent. We include in the Appendix the coding scheme, the rationale for case and model selection, figures that graph changes in NHRI strength over time and robustness checks.

We fit a series of pooled ordered logit models. Given that NHRIs have registered a natural increase in strength since 1994, we have included in all models a variable accounting for the time trend. 


\begin{tabular}{|c|c|c|c|}
\hline & $\begin{array}{l}\text { Model 1 } \\
\text { Strength }\end{array}$ & $\begin{array}{l}\text { Model } 2 \\
\text { Durability }\end{array}$ & $\begin{array}{l}\text { Model } 3 \\
\text { Enforcement }\end{array}$ \\
\hline GANHRI & $\begin{array}{l}0.893 * * * \\
(0.301)\end{array}$ & $\begin{array}{l}1.446 * * * \\
(0.275)\end{array}$ & $\begin{array}{l}0.193 \\
(0.252)\end{array}$ \\
\hline EUmem & $\begin{array}{l}0.938 * * \\
(0.450)\end{array}$ & $\begin{array}{l}0.237 \\
(0.368)\end{array}$ & $\begin{array}{l}0.606 \\
(0.404)\end{array}$ \\
\hline EUMemCond & $\begin{array}{l}2.056 * * * \\
(0.427)\end{array}$ & $\begin{array}{l}1.603 * * * \\
(0.351)\end{array}$ & $\begin{array}{l}1.622 * * * \\
(0.352)\end{array}$ \\
\hline ENPmem & $\begin{array}{l}0.103 \\
(0.388)\end{array}$ & $\begin{array}{l}0.552 \\
(0.358)\end{array}$ & $\begin{array}{l}0.405 \\
(0.329)\end{array}$ \\
\hline GHRTreat & $\begin{array}{l}0.280 \\
(0.409)\end{array}$ & $\begin{array}{l}0.268 \\
(0.301)\end{array}$ & $\begin{array}{l}0.291 \\
(0.484)\end{array}$ \\
\hline EHRTreat & $\begin{array}{l}0.126 \\
(0.094)\end{array}$ & $\begin{array}{l}0.103 \\
(0.071)\end{array}$ & $\begin{array}{l}0.241 * * \\
(0.111)\end{array}$ \\
\hline FHStatus & $\begin{array}{l}0.123 \\
(0.289)\end{array}$ & $\begin{array}{l}0.130 \\
(0.286)\end{array}$ & $\begin{array}{l}0.417 \\
(0.260)\end{array}$ \\
\hline NewDem & $\begin{array}{l}2.837 * \\
(1.537)\end{array}$ & $\begin{array}{l}1.898^{*} \\
(1.122)\end{array}$ & $\begin{array}{l}2.416 \\
(1.855)\end{array}$ \\
\hline Englo & $\begin{array}{l}0.323 \\
(2.281)\end{array}$ & $\begin{array}{l}0.938 \\
(1.686)\end{array}$ & $\begin{array}{l}-0.805 \\
(2.681)\end{array}$ \\
\hline GDPcap & $\begin{array}{l}-0.001 * * \\
(0.000)\end{array}$ & $\begin{array}{l}-0.001 * \\
(0.000)\end{array}$ & $\begin{array}{l}2.570 \\
(0.000)\end{array}$ \\
\hline trend & $\begin{array}{l}0.256 \text { *** } \\
(0.028)\end{array}$ & $\begin{array}{l}0.213 * * * \\
(0.025)\end{array}$ & $\begin{array}{l}0.196 * * * \\
(0.024)\end{array}$ \\
\hline $\mathrm{N}$ & 1200 & 1200 & 1200 \\
\hline
\end{tabular}

Standard errors in parentheses;

Prob $>\operatorname{chi} 2=0.000 ;(* * * \mathrm{p}<0.01 ; * * \mathrm{p}<0.05)$

The results of our analysis offer insights into possible causal processes explaining NHRI strength in Europe. We study the effects of the main international determinants membership in GANHRI through accreditation, EU membership, CoE influence, and EU 
conditionality - on institutional strength (model 1) and the two separate dimensions of institutional strength (models 2 and 3). Our results indicate that over time, countries that are members of GANHRI have comparatively stronger institutions than countries that are not members. This result furthers the conclusions of recent research on the design of NHRIs (Linos and Pegram 2016b) - membership in GANHRI, granted through the accreditation process and maintained through periodic re-accreditation, matters also for institutional strength and these effects are also felt over time. Given that our study is the first to expand the finding to nonaccredited institutions, the results add further evidence that a country's decision to seek accreditation and join GANHRI is associated with an increase in NHRI strength over time.

Our analysis provides valuable nuance to existing work on the influence of GANHRI. Models 1 and 2 show that the impact of GANHRI remains significant and positive on NHRI strength, particularly its durability. GANHRI's effect on enforcement safeguards is positive, but it is not statistically significant. While the influence of GANHRI as a global network could explain the stronger independence and autonomy from government, it could not account for states granting NHRIs stronger enforcement safeguards. The more 'shallow' commitment to enforcement safeguards, as reflected in the predominant activities of NHRIs to promote and protect human rights, may be due to incomplete learning and persuasion. At the institutional level, our findings point in the direction of institutional isomorphism due to acculturation processes, rather than the complete internationalisation of norms about the appropriate design of independent national bodies charged with the promotion and protection of human rights.

Our analysis provides strong evidence that EU membership conditionality has a positive and statistically significant effect on NHRI strength and on both dimensions of durability and enforcement. Even when the effect of EU membership does not reach the level of statistical significance, as is the case with the effect on the NHRI durability and enforcement safeguards, the impact of EU membership conditionality remains positive and significant. Our 
findings lend additional empirical evidence to existing scholarship on the impact of EU conditionality on institutional strength and compliance with EU legislation (Sedelmeier 2009) and reinforce qualitative findings on the instrumental role of coercive policies, such as in Bosnia and Kosovo, in stopping violent ethnic cleansing and have aided in curbing human rights violations in Estonia and Latvia (Schimmelfennig 2006, p. 257-260).

We provide some evidence in support of the thesis that the EU can be a promising case for persuasion and norm learning, but this evidence does not hold along both dimensions of institutional strength. Membership in the EU has a positive and statistically significant effect on institutional strength, as evidenced by model 1 , but these effects lose statistical significance when measured on the two disaggregated dimensions - durability and enforcement. However, the impact of membership in the ENP on NHRI strength is positive, but does not reach the level of statistical significance. Our analysis finds evidence of norm learning through international mechanisms coordinated by the $\mathrm{CoE}$, in the case of safeguards for enforcement. Although the statistical effect is small, states' commitment to European human rights treaties is associated with an increase in the NHRI safeguards for enforcement.

States' early efforts to democratise can be marginally significant predictors of an increase in NHRI strength, in particular in terms of durability safeguards. By comparison, the effect of overall levels of democracy on NHRI strength in Europe does not reach statistical significance, indicating that more significant growth in institutional strength occurs in periods of democratic transition. By this logic, changes in NHRIs strength are also tied to domestic political calculations that take into account the costs and potential benefits of institutional change when supporting a 'lock-in' of democratic reforms (Moravcsik 1995; Simmons 2009). Other domestic variables, such as GDP/capita, whether or not a country has a common law system have negative but small effects on NHRI strength, which do not remain significant across both dimensions of NHRI strength. 


\section{Case studies}

To illustrate the findings of our statistical analysis, we propose a qualitative inquiry exploring how NHRI strength has developed in response to international and domestic factors in Hungary and Poland. We select the two cases on the main independent variables in our study - they joined the EU in 2004, are newly democratised and host UN accredited NHRIs. Importantly, in recent years, the two NHRIs have operated in increasingly illiberal political environments. Despite a decline in government support for human rights, the two NHRIs have largely maintained their strength. As the Hungarian case will show, an NHRI can see its strength increase in a domestic environment that is hostile to human rights. Despite improved formal compliance, the risk of government interference in institutional activities remains high if institutional independence is not safeguarded by transparent and pluralist practices of appointment in NHRI leadership.

Forerunners of democratic transformation in the region (Schimmelfenning et al 2006), Hungary and Poland began efforts to establish parliamentary ombudsmen in the late 1980s, through amendments to national constitutions. They emerged out of the national momentum toward democratic change, signalling commitment to democratic reform (Archimowicz 2002), meeting the criteria for membership in the $\mathrm{CoE}$, guaranteeing the rights of ethnic and national minorities, and addressing international security concerns (Cardenas 2014, p. 260).

In Hungary, the first Ombudsman Act was presented before Parliament in 1993 with the recommendation that: ' $(. .$.$) its adoption may create an important guarantee in Hungary for$ respecting human rights and citizens' rights.' (OBH 2008). Four different independent Parliamentary Commissioners were created in 1995: Parliamentary Commissioner for Civil 
Rights, General Deputy Parliamentary Commissioner, Parliamentary Commissioner for Data Protection and Parliamentary Commissioner for the Rights of National and Ethnic Minorities. The resulting institutional set-up was unique to Hungary and was generally regarded as successful (OBH 2008).

Poland was the first CEE country to found its Ombudsman in 1987. Paradoxically, the authoritarian government of Poland vested its ombudsman with a much broader mandate than counterpart institutions in other countries, particularly regarding the constitutional control of legal acts and of the administration of justice. The ideological homogeneity of parliament at the time was a guarantee of full control of the ombudsman, regardless of its mandated strength (Arcimowicz 2002). Despite concerns that the ombudsman would not survive the transition from communism to democracy, it continued to function successfully and has been considered one of the most effective in the region.

The independent institutional progress toward democratic consolidation was reflected in the regular reports assessing performance toward EU accession in 2004. The first reports, issued in 2000, assessed that the existing ombudsmen in the two countries were strong and exercised their mandates effectively (EC 2000a; EC 2000b). The European Commission commended both ombudsmen's semi-judicial powers and relied on evidence provided by the ombudsmen to assess the countries' progress toward democratisation. The only ombudsman body whose mandate is amended as a result of the regular reports is Hungary's Commissioner for Data Protection, whose enforcement safeguards were strengthened by endowing it with investigative powers (OBH 2008).

NHRIs in both countries became stronger over the years, but at different moments in time and in response to different international and domestic factors. The Polish ombudsman sought accreditation with the OHCHR in 1999, when the Ombudsman was granted A-status. It has maintained compliance with the Paris Principles ever since, in three subsequent rounds of 
re-accreditation. Poland broadened the mandate of its ombudsman in 2010, endowing it with authority to prevent violations of the principle of equal treatment.

Since 2015, the national-conservative Law and Justice party has been the largest in the Polish Parliament and has passed laws limiting the powers of the Constitutional Court, extending control over TV and radio, and merging the functions of the formerly independent Prosecutor General (Human Rights House 2016). The Ombudsman has been faced with challenges in carrying out its mandate, even if at the time of writing, the mandate of the Polish Ombudsman has not been amended. In October 2016, the European Network of NHRIs (ENNHRI) and the International Ombudsman Institute issued a joint statement expressing concern regarding the human rights situation in Poland and the potential threats to the Ombudsman's independence (ENNHRI 2016). They re-affirmed the strength of the Polish ombudsman and its maintained independence, recommending a continued A-status of accreditation.

Although the formal strength and the main activities of the Ombudsman institution have not changed, overall government support for the institution has decreased since 2015 . The government has not adjusted the institutional budget to changes in inflation and has not supported the increase in financial and staff resources in response to the broadening of institutional mandate in 2010. This leaves the institution vulnerable to decreased future staff attrition and can lead to more limited effectiveness to carry out its mandate. In addition, the current Ombudsman, Adam Bodnar, has been the object of increased public attacks in rightwing mass media. This seeks to diminish the public credibility of the institution. In a hostile environment, the Ombudsman's strong collaboration with civil society organisations in the field of human rights is perceived as a bias in favour of the protection of the rights of minorities and in direct opposition to Polish nationalist and religious values. 
The most significant changes to the formal features of the ombudsmen took place in Hungary in recent years. Unlike other countries in the region, Hungary did not apply for accreditation with GANHRI until 2011, when it came under pressure from the Universal Periodic Review process and put forward the broadest of its independent bodies (Cardenas 2014). The Subcommittee on Accreditation (SCA) found the Commissioner partly in compliance with the Paris Principles. Although its existence was enshrined in the country constitution, the SCA expressed concerns primarily with the limited scope of the human rights mandate, very limited in promotional powers and pluralism (SCA 2013).

Orban's government took office in 2010 on a populist campaign of illiberalism and began a comprehensive process of constitutional reform that affected the existing ombudsmen institutions. The new constitution in 2012 promised to meet international requirements and called for major institutional changes through the establishment of a single ombudsman office, with continued quasi-judicial powers and a complaint-handling mandate and strengthened promotional powers that include research, education activities and specialised reporting (Ministry of Justice 2011). Following these reforms, in October 2014, the SCA found the unified Commissioner's office in full compliance with the Paris Principle, granting it A-status (SCA 2014). In 2015, the powers of the Commissioner were extended to encompass also the role of National Preventive Mechanism, through amendments to the Ombudsperson's Act.

The recent increase in the formal strength of the institution has not been matched by a consistent increase in the level of institutional activity. The rights promotion activity has decreased, and the primary focus of institutional activity has remained on handling complaint cases. The institutional response to the protection of refugees' rights during the large influx of refugees and asylum seekers in the 2015 and 2016 is a case in point. While the Commissioner considered a large amount of cases regarding complaints about the Hungarian authorities' management of borders $(2,640$ in total in 2016), the broader public institutional response to 
rights violations was limited. The Commissioner did not openly criticise the government's response to the humanitarian crisis, nor did it exercise its right to raise concerns about the adequacy of government policies in front of Parliament. Response was limited to issuing a public communique on the broader need for government officials and the police to follow international human rights law and curb consistent violations of the rights of refugees.

Although the ombudsmen in Hungary and Poland have maintained their formal strength over the years and are largely compliant with the Paris Principles, recent changes to the mandate of the Hungarian Ombudsman offer a window for possible future weakening of NHRI's effectiveness. The lack of transparency in the appointment process of the two ombudsmen and their deputies (SCA 2012; SCA 2014; TI 2012) gives way to political interference in the appointment process. In fact, the appointment in 2013 of Commissioner, László Székely, has raised concerns in the international NHRI community and amongst civil society in Hungary, due to the Commissioner's past political affiliation with FIDESZ and his active career in government since the 1990s. Such political sympathies can interfere with the mandated institutional powers that required it to act as an independent monitoring and accountability body in relation to government.

By centralising power in the single position of the Commissioner for Fundamental Rights, the recent reform in Hungary granted more power to the single-headed institution. In doing so, it weakened the Commissioner for Future Generations and the Commissioner for Minorities, by turning them into deputies that are no longer directly accountable to Parliament. In a domestic environment where the effectiveness of a public institution depends to a large extent on the ability of its leadership to remain independent from government and corruption (TI 2012, p. 38), these mandate changes can also be seen as a warning signal for an increased risk of capture. 


\section{Conclusion}

This paper has proposed an original analysis of institutional strength, by examining regional patterns of NHRI strength in Europe. Empirically, we propose the first index of institutional strength of NHRIs on two main dimensions of safeguards - durability and enforcement, - and eleven indicators. Because our dependent variable is not binary, but rather a composite indicator, it captures more accurately change in institutional strength across borders and across time. We further the research on NHRI design by expanding the scope of existing scholarship, which has so far focused primarily on countries that are members of GANHRI, and including in the data set both accredited NHRIs and non-accredited institutions. We also propose the first study of change in NHRI strength over time.

The analysis adds much-needed empirical data to debates on institutional strength, norm diffusion, and human rights. Further analysis is certainly needed to understand fully European states' human rights performance, by exploring change in institutional strength as well as its impact on human rights outcomes. Given our data, however, it is possible to offer important comparative insights into the evolution and determinants of NHRI strength in the region and into the main motivations for governments' commitments to supporting strong NHRI design in the region. As countries become members of GANHRI, their NHRIs are more likely to become stronger over time and show a general pattern of isomorphism regarding stronger safeguards for durability. Countries that are EU members are more likely to support strong NHRIs on their territories compared to states that hold candidate or ENP member status. These findings suggest that the influence of the EU on institutional strength may be tied to 
processes of norm sharing through learning and persuasion, which are more effective once countries are integrated in the network of member states.

We find strong support for a significant impact of EU conditionality on institutional strength, across both dimensions of strength. In addition, we find that commitment to regional human rights treaties is associated with stronger safeguards of institutional enforcement. This can be an indication of the influence that the CoE has had on the development of domestic human rights mechanisms, offering support for NHRIs to become more effective in carrying out their mandates. At the same time, positive changes in democratic outcomes in newly democratising states are associated with stronger NHRIs, particularly with safeguards for durability. This can be evidence of efforts to increase the stability of NHRIs over time as part of domestic elites' strategy to safeguard democratic progress and mitigate the risk of institutional decline in the event of possible future democratic backsliding.

While Europe is different from other regions, not least by having a densely institutionalised liberal community and NHRIs that have more rigorous systems of annual reporting, we expect that the methodological and theoretical insights in our study can be extrapolated to both the scholarly and the policy-focused study of NHRI strength in other part of the world. First, our operationalisation and the original coding scheme can be applied to the over-time study of change in NHRI strength in other regions. The extraction of over-time data, however, is dependent upon the availability of institutional annual reports for the years included in the study. Drawing from our findings and theoretical insights, comparative studies of NHRI strength can test hypotheses that seek to explain the role of global and regional IOs as well as the importance of democratisation efforts for human rights institutional performance.

Conceptually, this paper makes a contribution to the scholarship of institutional strength at the regional level, by providing a mechanism-based analysis of social influence of two IOs, the UN and the EU, on the strength of one national institution in fifty different countries. Our 
study is the first to illustrate that variation in the institutional strength of NHRIs can be studied not only across countries, but also across time. In our analysis that spans twenty years, we are able to capture change in institutional safeguards for durability and enforcement, advancing knowledge of the complex associations driving the influence of regional and global IOs, such as the EU and the UN, on countries' behaviour in a region with one of the longest and most dynamic traditions of human rights promotion and protection. 


\section{Biographical note}

Corina Lacatus is Career Development Fellow at the University of Edinburgh, UK.

\section{Correspondence address}

Department of Politics and International Relations, University of Edinburgh

Crystal Macmillan Building, Edinburgh, EH8 9LD

Edinburgh, United Kingdom

Email: $\underline{\text { C.Lacatus@ed.ac.uk }}$

\section{Acknowledgements:}

The author thanks the journal editors and the anonymous reviewers for very helpful comments and is grateful for generous feedback at earlier stages of research from Ulrich Sedelmeier, Shaun Bevan, Pilar Elizalde, Mathias Koenig-Archibugi, Tom Pegram, Brian Burgoon, Jon Pevehouse, and Duncan Snidal.

\section{Online supplemental material to be hosted by the publisher:}

Supplemental data for this article can be accessed at [link to source - publisher will add doi at proof]

[Heading:] Replication materials

Supporting data and materials for this article can be accessed on the Taylor \& Francis website, doi: [publisher to add the doi at proof]. 


\section{References}

Arcimowicz, J. (2002) 'The Ombudsman-One of the Figures in the Drama of the Third Republic', Polish Sociological Review 140: 427-448.

Börzel, T. A. . R. (2012) 'When Europeanisation Meets Diffusion: Exploring New Territory', West European Politics 35: 192-207.

Cardenas, S. (2003) 'Emerging Global Actors: The United Nations and National Human Rights Institutions', Global Governance 9.1: 23-42.

Cardenas, S. (2014) Chains of Justice: The Global Rise of State Institutions for Human Rights, Philadelphia: University of Pennsylvania Press.

Cardenas, S. and Flibbert, A. (2005) 'National Human Rights Institutions in the Middle East', Middle East Journal 59.3: 411-436.

Carver, R. (2011) 'One NHRI or Many?: How Many Institutions does it Take to Protect Human Rights? Lessons from the European Experience', Journal of Human Rights Practice 3.1: 1-24.

Carver, R. (2014) Measuring the impact and development effectiveness of national human rights institutions: a proposed framework for evaluation, Bratislava: UNDP Bratislava Regional Centre.

Checkel, J. T. (2005) 'International Institutions and Socialization in Europe: Introduction and Framework', International Organization 59.4: 801-826. 
Conant, L. (2014) 'Compelling criteria? Human rights in the European Union', Journal of European Public Policy 21.5: 713-729.

Council of Europe (1997) Establishment of Independent National Institutions for the Promotion and Protection of Human Rights, Recommendation No R(97)14, available at https://rm.coe.int/16804fecf5 (accessed March 2018).

de Beco, G. (2007) 'National Human Rights Institutions in Europe', Human Rights Law Review 7.2: 331-370.

EC (2000a) Regular Report on Hungary's Progress towards Accession, European Commission, available at https://tinyurl.com/ya2bvcd8 (accessed April 2018).

EC (2000b) Regular Report on Poland's Progress towards Accession, European Commission, available at https://tinyurl.com/ya2bvcd8 (accessed April 2018).

ENNHRI (2016) ENNHRI Statement of Support for Poland's Commissioner for Human Rights,

Finnemore, M. (1993) 'International Organizations as Teachers of Norms: the United Nations Educational, Scientific, and Cultural Organization and Science Policy', International Organization 47.4: 565-597.

Finnemore, M. and Sikkink, K. (1998) 'International Norm Dynamics and Political Change', International Organization 52.4: 887-917.

Goodman, R. and Jinks, D. (2013) Socializing States: Promoting Human Rights through International Law, Oxford: Oxford University Press. 
Goodman, R. and Pegram, T. I. (2012) Human rights, state compliance, and social change: assessing national human rights institutions, New York: Cambridge University Press.

Hafner-Burton, E. M. (2005) 'Trading Human Rights', International Organization 59: 593629.

Hafner-Burton, E. M. (2009) Forced to Be Good: Why Trade Agreements Boost Human Rights, Ithaca, NY: Cornell University Press.

Hafner-Burton, E. M. and Ron, J. (2009) 'Seeing Double’, World Politics 61.2: 360-401.

Hatch, E. (1989) 'Theories of Social Honor', American Anthropologist 91: 341-353.

Human Rights House (2016) Rule of law under threat in Poland, available at http://humanrightshouse.org/Articles/21739.html (accessed April 2018).

Jachtenfuchs, M. (2001) 'The Governance Approach to European Integration', Journal of Common Market Studies 39.2: 245-264.

Johnston, A. I. (2001) ‘Treating International Institutions as Social Environments', International Studies Quarterly 45.4: 487-515.

Keck, M. E. and Sikkink, K. (1998) Activism Beyond Borders: Advocacy Networks in International Politics, Ithaca NY: Cornell University Press.

Kelley, J. G. (2004) Ethnic Politics in Europe, Princeton, N.J: Princeton University Press.

Kim, D. (2013) 'International nongovernmental organizations and the global diffusion of national human rights institutions', International Organization 67.3: 505-539.

Kohler-Koch, B. and Eising, R. (1999) The Transformation Governance in the European Union, London: Routledge. 
Koo, J.-W. and Ramirez, F. O. (2009) 'National Incorporation of Global Human Rights: Worldwide Expansion of National Human Rights Institutions, 1966-2004', Social Forces 87.3: 1321-1354.

Lacatus, C. (2018) 'Human rights networks and regulatory stewardship: An analysis of a multi-level network of human rights commissions in the United Kingdom', The British Journal of Politics and International Relations 20.4: 809-826.

Levitsky, S. and Murillo, M. V. (2009) 'Variation in Institutional Strength', Annual Review of Political Science 12.1: 115-133.

Levitsky, S. and Murillo, M. V. (2013) 'Building Institutions on Weak Foundations', Journal of Democracy 24.2: 93-107.

Levitz, P. and Pop-Elechies, G. (2010) 'Why no backsliding?', Comparative Political Studies 43.4: 457-485.

Linos, K. and Pegram, T. (2016a) 'Architects of Their Own Making: National Human Rights Institutions and the United Nations', Human Rights Quarterly 38.4: 1109-1134.

Linos, K. and Pegram, T. (2016b) 'The Language of Compromise in International Agreements', International Organization 70.3: 587-621.

Linos, K. and Pegram, T. (2017) 'What Works in Human Rights Institutions?', American Journal of International Law 111.3: 628-688.

Manners, I. (2002) 'Normative Power Europe: A Contradiction in Terms?', Journal of Common Market Studies 40.2: 235-258. 
Mertus, J. (2009) Human Rights Matters: Local Politics and National Human Rights Institutions, Stanford, CA: Stanford University Press.

Meyer, J. W. and Rowan, B. (1977) 'Institutionalized Organizations: Formal Structure as Myth and Ceremony', The American Journal of Sociology 83.2: 340-363.

Ministry of Justice (2011) The Fundamental Law of Hungary, available at http://www.kormany.hu/download/a/68/11000/The_Fundamental_Law_of_Hungary_ 01072016.pdf (accessed April 2018).

Moravcsik, A. (1995) ‘Explaining international human rights regimes', European Journal of International Relations 1.2: 157-189.

Moravcsik, A. (2000a) 'The Origins of Human Rights Regimes: Democratic Delegation in Postwar Europe', International Organization 54.2: 217-252.

Moravcsik, A. (2000b) 'The Origins of Human Rights Regimes: Democrratic Delegation in Postwar Europe', International Organization 54.2: 217-252.

Murray, R. (2007) The Role of National Human Rights Institutions at the International and Regional Levels, Oxford, UK: Hart Publishing.

OBH (2008) The Hungarian Ombudsman Institution (1995-2008), Parliamentary Commissioners' Office.

OHCHR (2016) Principles relating to the Status of National Institutions, 2016, available at http://www.ohchr.org/EN/ProfessionalInterest/Pages/StatusOfNationalInstitutions.asp x (accessed March 2018). 
Pegram, T. (2010) 'Diffusion across political systems: the global spread of national human rights institutions', Human rights quarterly 32.3: 729-764.

Powell, W. W. and DiMaggio, P. (1991) The new institutionalism in organizational analysis, Chicago: University of Chicago Press.

Reif, L. C. (2004) The Ombudsman, Good Governance and the International Human Rights System, Leiden/Boston: Martinus Nijhoff Publishers.

Risse, T. (2000) 'Let’s Argue!' Communicative Action in Internatioal Relations', International Organization 54.1: 1-39.

Risse-Kappen, T., Ropp, S. C. and Sikkink, K., 1955 (1999) The power of human rights: international norms and domestic change, Cambridge: Cambridge University Press.

Roberts, A. (2010) The Quality of Democracy in Eastern Europe, Cambridge: Cambridge University Press.

SCA (2012) Report and Recommendations, Geneva: International Coordinating Committee of National Institutions for the Promotion and Protection of Human Rights.

SCA (2014) Report and Recommendations of the Session of the Sub-Committee on Accreditation,

Schimmelfennig, F. (2012) 'EU external governance and Europeanization beyond the EU', in D. Levi-Faur (ed.). Oxford Handbooks in Politics \& International Relations. Oxford: Oxford University Press.

Schimmelfennig, F., Engert, S. and Knobel, H. (eds) (2006) International Socialization in Europe, New York: Palgrave Macmillan. 
Schimmelfennig, F. and Sedelmeier, U. (2004) 'Governance by Conditionality: EU Rule Transfer to the Candidate Countries of Central and Eastern Europe', Journal of European Public Policy 11.4: 661-679.

Schimmelfennig, F. and Sedelmeier, U. (eds) (2005) The Politics of European Union Enlargement: Theoretical Approaches, London ; New York: Routledge.

Sedelmeier, U. (2007) The European Neighbourhood Policy: A Comment on Theory and Policy, in K. Weber, M. E. Smith, and Baun (eds). Manchester: Manchester University Press, pp. 195-208.

Sedelmeier, U. (2009) Post-accession compliance with EU gender equality legislation in post-communist new member states,.

Sedelmeier, U. (2011) 'Europeanisation in new member and candidate states', Living Reviews in European Governance 6.1.

Shyrokykh, K. (2019) 'Policy-specific effects of transgovernmental cooperation: a statistical assessment across the EU's post-Soviet neighbours', Journal of European Public Policy 26.1: 149-168.

Simmons, B. A. (2002) Why Commit? Explaining State Acceptance of International Human Rights Obligations, available at http://www.is.gd/yVx92p (accessed February 2014).

Simmons, B. A. (2009) Mobilizing for Human Rights. International Law in Domestic Politics, New York: Cambridge University Press.

Simmons, B. A., 1958, Dobbin, F. and Garrett, G., 1958 (2008) The global diffusion of markets and democracy, Cambridge, UK: Cambridge University Press. 
Simmons, B. A., Dobbin, F. and Garrett, G. (2006) 'Introduction: the international diffusion of liberalism', International Organization 60 (Fall): 781-810.

Simmons, B. A. and Elkins, Z. (2004) 'The globalisation of liberalisation: policy diffusion in the international political economy', American political science review 98 (February): $171-189$.

Smith, A. (2006) 'The Unique Position of National Human Rights Institutions: A Mxed Blessing', Human Rights Quarterly 28: 904-946.

TI (2012) Corruption Risks in the Visegrad Countries, Hungary: Transparency International, available at http://www.transparency.sk/wp-content/uploads/2012/07/visegrad_net.pdf (accessed April 2018).

UN General Assembly (1993) Resolution A/RES/48/134, available at http://www.un.org/documents/ga/res/48/a48r134.htm (accessed March 2018).

Vachudová, M. A. (2005) Europe undivided: democracy, leverage, and integration after communism, Oxford; New York: Oxford University Press.

Welch, R. M. (2017) 'Domestic politics and the power to punish: The case of national human rights institutions', Conflict Management and Peace Science 1-20.

Wouters, J., Meuwissen, K. and de Barrios, A. S. (2013) The European Union and National Human Rights Institutions, Working Paper No. 112,.

Yzer, M. (2012) 'Reasoned Action Theory: Persuasion as Belief-Based Behavior Change', in J. P. Dillard and L. Shen (eds). The Sage Handbook of Persuasion. Thousand Oaks CA: SAGE, pp. 120-137. 
Zucker, L. G. (1987) 'Institutional Theories of Organization', Annual Review of Sociology 13: $443-464$. 